\title{
Gender Issues in my Work
}

\author{
Evelyn Conlon
}

Copyright (c) 2018 by Evelyn Conlon. This text may be archived and redistributed both in electronic form and in hard copy, provided that the author and journal are properly cited and no fee is charged for access.

Writers can be a bit like children who have learned how to tie their shoelaces - all well and good, job done, delighted with themselves, and then someone asks how they did it. Things are not so happy now. I don't like writing about writing but I'll dip my pen in the ink and see what happens.

I had two short stories published in a National newspaper, The Irish Press, written when I was 16, 17 or so, quite young now that I look at it. The editor of this page was a man called David Marcus, a much respected figure, a person who came to have a lot of say in how the Irish short story would look from the 1970s onwards. Or at least the ones that were published - not to mention lauded and prized. But somehow, after those two were written, my next endeavours were deemed not suitable, as we politely say. David's and my own paths had a serious divergence. My interests and subject matter changed. I wanted to write about how we - women, men, the entire country - were beginning to jump over the wall. I was affected, in the way that some writers are, by all that was happening around me. But those stories didn't fit on the national grid. Or on the manifest being compiled by men who could see the marketability of an Irish "list". The literary view of women was not keeping pace with the real lives that I was watching. No pageant was being made of our actual thoughts and of how we saw our world. Stereotyping reigned supreme. (And in many ways still does, having crept back in, wearing different clothes.) So I turned to writing bad poetry. I'm a great judge of bad poetry, having, in error, created some of it. I could not dare to write what I needed to, and thought to camouflage it by putting it in semi verse. I hadn't yet got the nerve to stand up to the consensus.

The process of realizing that fiction could facilitate new truths came quite suddenly. I can still feel it. I am in a room at the National Writers' Workshop in the Atlanta Hotel in Galway. Eavan Boland has obviously had a conversation with Bernard MacLaverty and I have shifted into the short story room. And in the middle of the first day a faint sound slid in. Joy Williams once said that the short story made her think: "assemble the ambulances; something is going to happen". I felt myself gearing up for the something. I returned to the short story, having realized in that room that I could allow myself to paint whiffs of portraits through fiction, and that is all a writer can do.

I had already begun reading beyond my place, beyond the accepted canon, but now I did it in earnest. I don't consider that I re-educated myself, I consider that I added to what I already knew, blazed a bit of extra light on my view, by first finding and then reading all 
these women who had been secretly kept locked down in the basement. The difficulties of the search itself told the story. And by my very reading, never mind my writing, I put myself outside the place intended for me. Briefly - with wonderful relief - I left aside all the male Irish writers who ought to have been ashamed of themselves for their myopia and the shadow dots of females they had created as background filler for their "real" exploits - sub-airportfiction characters, denuded of all life, nuance, and brain matter.

Looking back now, I imagine a picture of that time, as if it was taken unawares. I like the echo of photographs, the standing still that Manuela Palacios González gets us to observe in Ex-Sistere. An image is snapped years ago, forgotten about, then found in a drawer. We look at it again. We're fascinated by that unseen thing that has turned up in the background. It catches our eye, and rivets our attention. Writers who are women, as opposed to writers who are men, speak always in front of that unseen thing. It's a flag saying Look! it's a Woman Writer! I wasn't a writer for long before I became aware of this pennant, fluttering away behind me no matter what part of the room I occupied. Eventually I had to acknowledge it. I did, by reading those writers whom I had never known existed, and boy did I have the time of my life. They gave me the right to be truthful. But they, and my own work, added another flag behind me: A writer who is not compliant with the view we have of Irish women.

If only I had a chapter for every time I've been asked if I'm "a feminist writer". The answer is that no I'm not. I'm a writer who is a feminist. It doesn't take hard work to understand why I have to be a feminist. Simply put, I must not be the opposite. Of course the feminism that I espouse is not being anti man. How often have we had to say that with the stitched-on smile. Merciful hour it's not always about men. I'm all for men. I love some of them, like an awful lot of them, even though I've had reason to fall out with one or two. But I am also all for trying to understand women. I'm interested in the woman who is doing her best, the one who allows love to make her foolish, the one just barely holding on, and the one who is trying to change the world, even in small ways, to make it a better place, for women and for men. It follows that a better world will benefit men. Well, some of them. Certainly it will not benefit those who have always had uncontested power, because they're about to lose some of it, aren't they.

I write about women, men, and children, about Irish people and others. One of my novels, with the issue of capital punishment at its core, is about a man being wrongly executed for the murder of a woman. It's not about the woman, who deserves a tale all of her own. It then journeys on to Death Row in the USA. I write, sympathetically enough I think, about men. But the reason I have to answer the question so often is that I also write about women who are alive, wide awake, who are more than what they look like, who have views about how they fit in the world. "Surely that couldn't be a problem?" you say. But it is, because it upsets the script. The cries go up: "but what about the ordinary woman?" And I say: "there she is". So the gender issue in my work is not that I write about women, but that I don't constrain them, I allow them to think in crooked lines. And be as unique as humans are. The issue is that there is an issue about that at all.

The dual standard is a worldwide one, not exclusively Irish, well described, for instance, by Alberto Manguel in his introduction to Other Fires, an anthology with one of my favourite stories of all time, "The Fall", by Armonía Somers. I try to tell students about it, maybe making up extra bits around the fringes; it's hard not to. When I was attempting to write out from under the guilt inevitably bestowed upon us - Catholic in my case - this story was a shining light. Somers didn't just burrow her way out, she flew free in the first words, while at the same time having a thunderous respect for the poor captive's spiritual beliefs. Manguel understood the travesty of misrepresentation better than most. He had become frustrated by the academic shortchanging of Latin American literature. He set out in the 1980s to anthologize little-translated work. He was tired of the same three or four, and the magic 
realism trap, and the lazy term "Latin American Literature", because there can be no such thing - the continent is too vast and varied for that shorthand. He was bewildered by how translation choices were made, he had a copious list of neglected voices in his head. And became struck by the fact that there were so many women on it. Hence this jewel of an anthology, which opens up not just its own doors but a map to find other gems. I thought about it a lot as I chose work for Cutting the Night in Two.

When I travel abroad as a writer, I am continuously asked about male Irish writers, a situation that I suspect is not reciprocated. I often have to sew on that smile, yet again, when I say that work written by men about women is not the voice of women. You may find it odd that I should state such an obvious thing but regretfully I must. No matter how good the writer, no matter how wonderful he is at getting into the heads of his women characters as well as his men, he is not a woman's voice. I get exhausted even having to think this truth. Of course I'm not saying that men can't write about women, nor that white people can't write outside their colour, I am simply stating that I sometimes want to hear the original voice. And moreover, I want it to matter as much as the phantom one does. I want the unfiltered truth, not the one propped up by typically lazy preconceptions or romanticized guff. I am of course very aware that women can write that too - often with the enthusiastic backing of publishing houses and men who really prefer that view.

In the 1970s we learned that when the woman in the story is always dumb and available, when her greatest task is to wipe the flour from her nose before setting the table, when the black man is always the janitor and the black woman always the maid, in other words when the only people who are equal to white men are white men, there is something wrong with Art. I said "always". And I said "equal", meaning to be equally capable of being obnoxious, human enough to be bad rather than a cliché. I'm a great one for the Lady Macbeths. I'd prefer to be horrible than to be a cardboard cut-out.

I have on rare occasions tackled the gender issue head-on in my work. "Taking Scarlet as a Real Colour", the title story of a collection, ends with the speaker writing to Henry Miller, suggesting to him that men writing about sex may have got it wrong, may have suffered from a misunderstanding. Again, a title story, "Telling", is about a great male writer telling a roomful of women how to write about domestic violence. I had form here, having once, in fury, published an article in response to the portrayal of a woman suffering domestic violence, and having expressed bafflement at the narrow view of what constituted a family. At the time, I was myself a "separated" mother of two young boys, living in a hostile environment. The factual pressure of that, and my watching the wonderful way my sons were negotiating their difference, dulled any pedestrian sense of humour I could have had around the issue. Initially I didn't have any intention of addressing the issue publicly (why should I? no one else would). But then I could bear it no more. The reactions of women who had felt silenced and who contacted me in their droves to tell me of their relief might have suggested that I was right to do so. And yet, in some ways, I wish I had stayed silent. It's easier.

Of course, I would prefer not to be angry. Of course I'd like to be considered polite. I once stood up to gently ask if a speaker, in his mentioning of twenty-two Irish writers, might consider that perhaps only one woman gracing his mouth was a bit minimalist. As I began to formulate the dry throated words my brain said Oh god not me again.

Currently I'm working on a series of essays about my writing life, in its way a kind of memoir (but I don't like the word because of the presumption of the Me in it). In this I've been writing about a quite shocking act of censorship performed on my second collection by the already mentioned man who was considered the arbiter of the Irish Short Story at the time. The shock is not about him as a reader exhorting that it should not be published (every reader has that right) it is about the reasons given. When I look at his report, I realize that tackling 
gender issues within my work had a cost, a huge cost to me. I should say that the collection did get published, despite the obstacles thrown in its way.

The characters flaunting themselves, I hope, in my next collection are a variegated bunch of men and women. They include Violet Gibson, the Irish woman who almost succeeded in assassinating Mussolini; Mary Lee, the Irish woman at the forefront of getting the vote for women in South Australia; Sophie Brezeska who loved the French sculptor Henri Gaudier and rescued a considerable amount of his work after he was killed in the WW1 trenches. But it also includes a horrible woman who lies about the father of her child. And another who lies about herself. When I begin to write about a man or a woman I do not think of how the reader will see them. I simply run with what I know of the world, and a surprising enough place that is. I have three stories that could be in the voice of either gender, one from an academic who goes to interview the first woman to deliberately become pregnant after the atom bomb was dropped, one from a child who sits on the stairs listening to its sister lose the run of herself over her wedding. I've read these stories at events and it has been interesting, to say the least, listening to people explain why they know the characters are male or female.

I don't think about gender issues when I'm writing, I merely observe what happens between men and women, or what happens to women or men. But no doubt the shade of the things I see is affected by the colour code of my knowledge of the world.

PS-. It would be remiss of me not to mention the pageant we have had since I first wrote this essay. On 26 May I stood for hours in the square of Dublin Castle, surrounded by cheerful countrywomen and men, waiting to hear the numbers read out as we won the Referendum to attend to the abortion needs of our citizens. We had already surprised the world by being the first country to recognize same sex marriage by popular vote, on 22 May 2015. On that day I had known we were almost there. But still I have to smile on days when I realize what has been achieved. I went home that evening and wrote to close friends around the world, loving the passing on of good news. Some of them reread The Park and gave me their view of it now. So, I reread it, and smiled even more.

\section{Works Cited}

Conlon, Evelyn. Taking Scarlet as a Real Colour. Belfast: The Blackstaff Press, 1993. . Telling. Belfast: The Blackstaff Press, 2000. and Hans-Christian Oeser, eds., Cutting the Night in Two. Dublin: New Island, 2001.

Lorenzo-Modia, María Jesús, ed. Ex-Sistere. Cambridge: Cambridge Scholars Publishing, 2016.

Manguel, Alberto, ed. Other Fires. London: Picador, 1986.

Received: 22 June 2018

Evelyn Conlon is an Irish novelist and short story writer. She is an elected member of Aosdána, the Irish association which honours distinguished artistic work. She has been writerin-residence in colleges in many countries and at University College Dublin. A clear-sighted, observant and unsentimental thinker, her work is marked by originality and wit. Her most recent novel Not the Same Sky (Wakefield Press, 2013) steps back in time to tell the story of four young women who were among the 4000 orphaned Irish girls shipped to Australia following the Great Famine of 1847. Earlier novels include Skin of Dreams (Brandon Press, 2003), A Glassful of Letters (Blackstaff Press, 1998) and Stars in the Daytime (Women's Press, 1990). She has published three collections of short stories, My Head is Opening (Attic 
Press, 1987), Taking Scarlet as a Real Colour (Blackstaff Press, 1993), the title story of which was performed at the Edinburgh Theatre Festival, and Telling - New and Selected short stories (Blackstaff Press, 2001, Books Upstairs 2016), as well as editing four anthologies, including Cutting the Night in Two (New Island, 2001) and Later On (Brandon Press, 2004). Her stories have been widely anthologised and translated, most recently into Chinese and Tamil. 